\title{
Modelling soil properties from horizon depth functions and terrain attributes: An example with cation exchange capacity
}

\author{
Jude C. Obi a,*, Ifiok B. Udoh a, Innocent C. Obi b
}

a Department of Soil Science and Land Resources Management, University of Uyo, Uyo. Nigeria

b Department of Soil Science and Technology, Federal University of Technology, Owerri, Nigeria

\section{Article Info}

Received : 28.12.2018

Accepted : 19.09.2019

\begin{abstract}
The objective of this study was to, through the distribution of some soil properties, model cation exchange capacity (CEC) in soils formed on gently undulating coastal plain sands of southeastern Nigeria using genetic horizon functions and terrain attributes. A total of 19 profile pits were prepared, described and 104 genetic horizons were identified and sampled, processed and analysed in the laboratory. Data were generated on the soil characteristics, including particle size fractions, hydraulic conductivity, bulk density, organic carbon, $\mathrm{pH}$ and electrical conductivity. Terrain attributes that were generated from digital elevation model include aspect, compound topographic index (CTI), Flow direction, curvatures, slope and stream power index (SPI). Data generated were analysed using descriptive statistics, correlation and regression. The terrain attributes were modified with genetic horizon depths, bulk density and clay content for the modelling process. Sand content, bulk density and cation exchange capacity possess geogenic rather than pedogenic characteristics and were normally distributed. The indication is that the two groups of terrain attributes depended on the mass per unit area of soil and clay content in their influence on these ultisol profiles. Paired comparison, root mean square error and normalized root mean square error indicated that the model was a good fit and could be useful in the prediction of soil properties and management of coastal plain sands.
\end{abstract}

Keywords: Pedogenesis, terrain attributes, geogenesis, exchange complex, profile characteristics.

(C) 2020 Federation of Eurasian Soil Science Societies. All rights reserved

\section{Introduction}

Genetic horizons are imprints of pedogenesis that manifest in the characteristics of a pedon. The direction and progression of pedogenesis is largely dependent on the predominant factors of soil formation. The humid tropical environment characteristically encourages argeluviation -argiluviation with progression of pedogenesis. This is particularly manifest in the coastal plain sands that are dominantly sandy, kaolinitic and classified as ultisols (Lekwa and Whiteside. 1986) inherently low in organic matter content and fertility (Obi, 2015a; Obi et al., 2016).

Ultisols are highly leached, low in weatherable minerals, cation exchange capacity (CEC) and base saturation. The cation exchange capacity, which reflects the nature of the mineral component of the exchange complex, measures the quantity of negatively charged sites that can retain positively charged ions electrostatically and occurs in kaolinitic clays due to the broken bonds around the crystal edges, the substitutions within the lattice, and the hydrogen ions on exposed surface hydroxyls that may be exchanged (Ma and Eggleton, 1999). The effects of topography (as endogenous and exogenous factors of soil formation) on soil moisture characteristics has been reported (Seibert et al., 2007; Debella-Gilo et al., 2007; Behrens et al., 2010; Obi, 2015b). This relationship between soil water content and landscape is encapsulated in the digital terrain analysis (DTA) as a component of the environmental variables that influence pedogenesis and variability of

\footnotetext{
${ }^{*}$ Corresponding author.

Department of Soil Science and Land Resources Management, University of Uyo, Uyo. Nigeria

Tel.: +2348033497933
}

e-ISSN: 2147-4249

E-mail address: obijbc@yahoo.com DOI: $10.18393 /$ ejss.623325 
soil properties (Swarowsky et al., 2011). Therefore, terrain attributes influence pedogenesis and could be useful in the study of variations within the profiles of coastal plain sands. The dominant factors in the formation of ultisols have been associated with the influence of terrain attributes (Obi et al., 2014; Obi, $2015 b)$. Cation exchange capacity is a good indicator of pegogenesis and could be directly influenced by terrain attributes. Therefore this study modelled the cation exchange capacity of the coastal plain sands using terrain attributes and genetic horizon depth.

\section{Material and Methods}

\section{Study area}

The study was carried out in Akwa Ibom State located in the Southeastern Nigeria and enclosed between $4^{\circ} 30^{\prime}$ and $5^{\circ} 30^{\prime} \mathrm{N}$ and $7^{\circ} 28^{\prime}$ and $8^{\circ} 20^{\prime} \mathrm{E}$ (Figure 1). The climate is characterized by distinct rainy (March/April to October) and dry (November to March) seasons. There is bimodal rainfall distribution in each year with high intensity varying between $2000 \mathrm{~mm}$ in the northernmost part and $4000 \mathrm{~mm}$ along the coast (Udosen, 2014). Temperature is uniformly high averaging between $28{ }^{\circ} \mathrm{C}$ and $30{ }^{\circ} \mathrm{C}$ and relative humidity is high (approximately 75\%). Vegetation is characterized by secondary forest of predominantly wild oil palm trees of various densities, woody shrubs and various grass undergrowth.

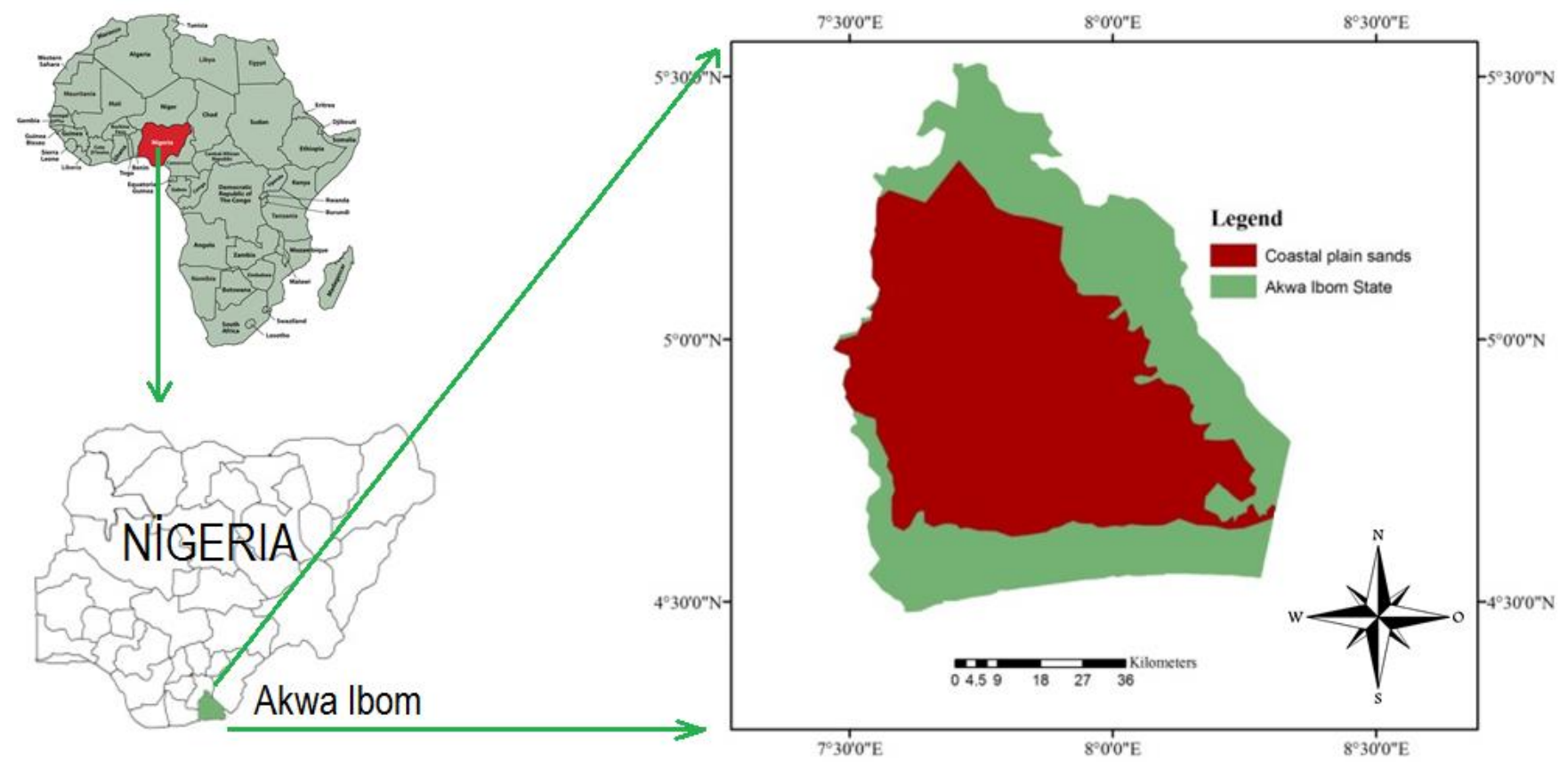

Figure 1. Map of Akwa Ibom State showing area covered by coastal plain sands

Soils of Akwa Ibom State are formed on six geomorphic units among which coastal plain sands constitute approximately 55\% (Figure 1). According to Ibia et al. (2015) the spatial coverage of these geomorphic units are beach ridge sands (9.4\%), tertiary sandstones (17.1\%), strongly undulating coastal plain sands (4.2\%), gently undulating coastal plain sands (51.2\%), mangrove mudflat $(6.5 \%)$ and alluvium covering $(11.6 \%)$. These are indications that coastal plain sands is the predominant material and could largely influence the extensive rain fed low input agricultural production system practiced in the area.

The profiles of the coastal plain sands are characterized by the dominance of sandy textured grains comprising higher proportion of coarse fractions over fine textured materials, low physical and chemical fertility due to dominance of low-activity kaolinitic clays, and low organic matter content (Ofomata, 1981; Ojanuga et al., 1981). They are well drained, deeply weathered, have udic moisture regime and isohypertermic temperature regime.

\section{Soil sampling and laboratory analysis}

A total of 19 profile pits were prepared and georeferenced (Table 1) to represent the landscape of the study area. The landscapes of coastal plain sands characteristically comprised upper, middle and lower slopes because they are largely gently undulating. The profile pits were described and sampled according to genetic horizons. There were between 5 and 6 horizons in the profiles and a total of 104 representative genetic horizons were identified and corresponding bulk and core samples collected for the study. The samples were processed and analysed in the laboratory for particle size fractions, bulk density and hydraulic conductivity 
using the method of Dane and Topp (2002). Organic carbon (OC) content was determined as described in Sparks (1996). Soil pH and electrical conductivity (EC) were determined in 1:2.5 (soil:water) solution using pH meter (McLean, 1982) and conductivity bridge (Rhoades, 1996), respectively. Cation exchange capacity (CEC) was determined by ammonium saturation $\left(\mathrm{NH}_{4} \mathrm{OAc}\right)$ displacement method conducted at $\mathrm{pH} 7.0$ following the approach by (Odu et al., 1986).

Table 1. Coordinates of representative profile pits sampled for the study

\begin{tabular}{llllll}
\hline Location & Latitude & Longitude & Location & Latitude & Longitude \\
\hline Atai obio ediene & 5.2111333 & 7.8278000 & Use offot & 5.0339333 & 7.9789500 \\
Atai obio ediene & 5.2111000 & 7.8287167 & Ntak inyang & 5.0787333 & 7.9250333 \\
Atai obio ediene & 5.2111333 & 7.8293333 & Uyo & 5.0546833 & 7.9395000 \\
Edem iyere & 5.1949167 & 7.8328167 & Uyo & 5.1270667 & 7.9595333 \\
Edem iyere & 5.1948833 & 7.8327167 & Use atai & 5.0485000 & 7.9751167 \\
Edem iyere & 5.1948833 & 7.8327000 & Ikot anyang & 5.0483833 & 7.9745833 \\
Etip ediene & 5.1945833 & 7.7977167 & Nduetong oku & 5.1406167 & 7.9677667 \\
Etip ediene & 5.1943667 & 7.7977333 & Uyo obio & 5.1540200 & 7.8322167 \\
Etip ediene & 5.1941000 & 7.7978667 & Uyo obio & 5.1539167 & 7.8328333 \\
Uyo obio & 5.1544000 & 7.8318000 & & & \\
\hline
\end{tabular}

\section{Terrain analysis}

Digital elevation model is differentiated into primary and secondary attributes. Primary terrain attributes including slope, aspect, curvatures, flow direction and hill shade, are estimates of local geomorphometric terrain characteristics. Secondary terrain attributes include compound topographic index or topographic wetness index and the sediment transport index or stream power index (Moore et al., 1993). The terrain attributes were generated from digital elevation model (DEM) using Spatial Analyst extension of Arcgis 9.2 of ESRI(C) (Figure 2), and sampling points were georeferenced and added as coordinates. The terrain attributes and sampling points were brought into the same Arcgis environment and thereafter the terrain attributes were extracted for further processing and analysis. The terrain attributes extracted include slope, aspect, total curvature, profile curvature, plan curvature, tangent curvature, flow direction, hill shade, stream power index and compound topographic index (Obi et al., 2014).

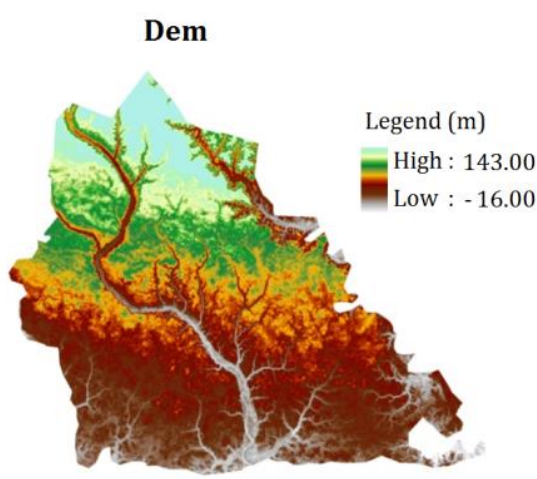

Pan curvature

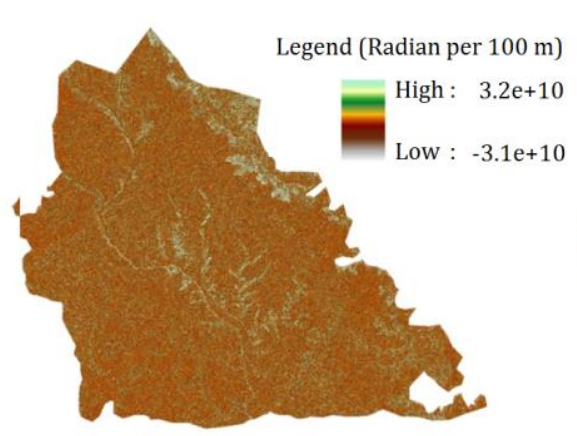

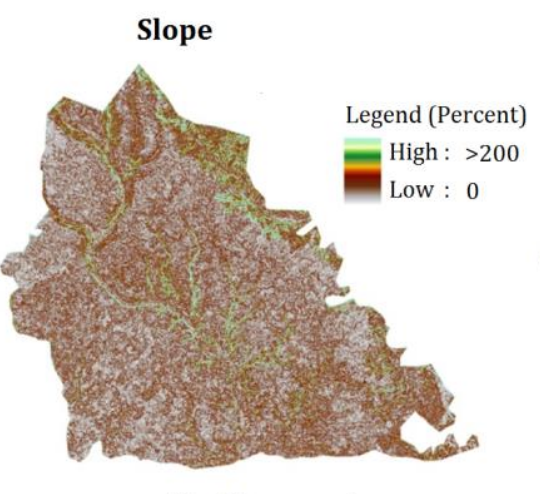

Profile curvature

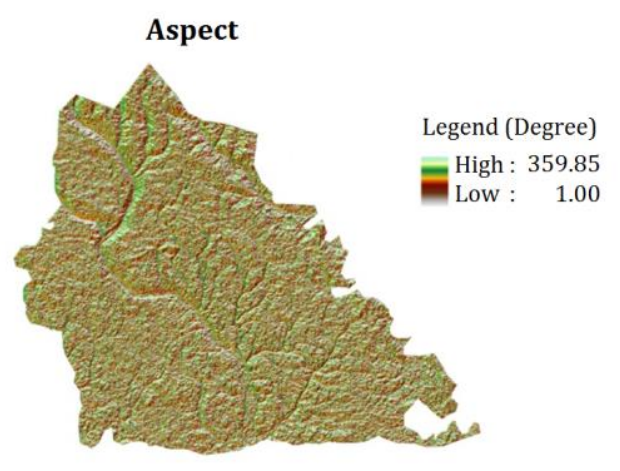

Tangent curvature

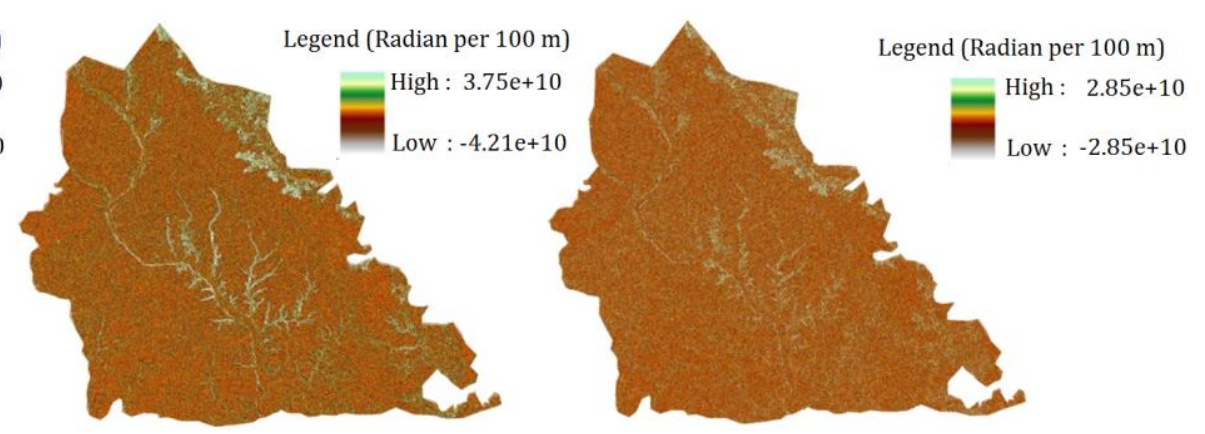

Figure 2. Some topographic attributes of coastal plain sands of south eastern Nigeria

Curvature of a surface at a point is the second derivative of the altitude or elevation and generally varies with orientation. Curvature is associated with gravity field constraints, measures related to stress fields, surface and subsurface water and sediment flows. Profile curvature (cp) is the rate of change of slope 
gradient (in the direction of greatest change), and contour or plan curvature (cc), the rate of change of direction of a contour line associated with a particular elevation reference field (Carson and Kirkby, 1972). Plan curvature is the rate at which flow direction changes with direction (i.e. following a contour line). Tangential curvatures (ct) are evaluated perpendicularly to slope gradient. Hill shade is the estimate of the intensity of the sun achieved using the altitude and azimuth properties. The stream power index is an estimate of effects of rainfall intensity and scouring inflow rate on runoff formation, soil erosion and solute transport on the surface runoff (Guo et al., 2010). Compound topographic index (CTI) reflects flow accumulation and is estimates as the ratio between the catchment area and slope. Stream power index is the erosive power of the terrain.

\section{Statistical analysis}

Soil profile pit characteristics and terrain attributes were analysed using descriptive statistics, correlation and regression. The descriptive statistics were used to summarise the soil profile characteristics of the study area and evaluate their distribution. Correlation analysis evaluated the relationship between the soil characteristics and the terrain attributes while regression was used to model the determinants of the variability of cation exchange capacity of the profiles of coastal plain sands. In the stepwise multiple regression analysis, both genetic horizon depth and bulk density were used as modifiers for the terrain attributes as an indication of the soil mass. Bulk density is influenced by the amount of organic matter, texture, constituent minerals and porosity. Soil bulk density measurements are often required as an input parameter for models that predict soil processes. Such models often use bulk density measurements to account for horizon mass when aggregating soil data (Chaudhari et al., 2013). Each profile should possess same terrain attributes but the influences of the attributes are not the same at different portions of the profiles as could be differentiated with genetic horizons. Equally, soil bulk density varies with depth and their interactions with factors of soil formation manifests in the characteristics of different genetic horizons.

Predictability of cation exchange capacity was evaluated using analysis of variance and significantly different means were compared with least significant difference $(p<0.05)$. Further evaluation of the accuracy of prediction was carried out using root mean square error (RMSE) and normalized root mean square error (NRMSE). Root mean square error compares predicted and observed values through the aggregation of residual to a single measure of predictive power. Normalization transforms RMSE into dimensionless quantities and renders them suitable for direct comparison especially of variables that have different units. Statistical analysis system (SAS)/STAT® software version 9.2 for Windows (SAS Institute, 2011) was used to perform the statistical analyses.

\section{Results and Discussion}

\section{Distribution of soil properties within the study area}

The distribution of the soil properties within the study area were as shown in Table 2. Normality of distribution of the soil variable determined in this study was used as indication of the characteristics of the representative profiles. It was not expected that the characteristics of the profiles will be homogenous within the study area. This is explained by the fact that pedogenesis is a process that depends on diverse factor and these act independently. Hence the combination at different rates could lead to different degrees of variations. For instance the distribution of the horizon depth of the profiles was not normally distributed as other variables with the exception of sand, bulk density and cation exchange capacity. It was expected that even at non-normal distribution, variable that originated from the same population should have the indicator of the central tendencies (mean, median and mode) to fall within the same periphery indicating that though they are not normally distributed, yet they are neither skewed nor kurtosis. This event has been reported for the coastal plain sands (Obi and Udoh, 2011). The non-normal distribution is anticipated because the characteristics of the pedons are manifestations of pedogenesis and as the samples are not uniformly from a single horizon but a combination of different horizons of different slope configurations. Then they are not expected to be a representation of a single population. Coastal plain sands are formed from pedogenic processes characterized by the dominance of sand fractions (Obi, 2015b). The major point of deviation is the different configuration and slope forms from which the profiles were formed. These are not expected to lead to the formation of similar features or profile characteristics as they have been used in the differentiation of soil classes on both sedimentary and metamorphic materials (Moss, 1957; Smyth and Mongomery, 1962).

The normally distributed soil properties $(\mathrm{Pr}<\mathrm{W})$ as shown in Table 2 established with the aid of Shipiro Wilk test (Shapiro and Wilk, 1965) included sand content, bulk density and cation exchange capacity. It is 
established that the most common feature of the coastal plain sands is the dominance of the sand particles, low-activity kaolinitic clays, and low organic matter content (Ofomata 1981; Ojanuga et al., 1981). This characteristic is inherited by the profiles from their mineralogy (quartz arenitic) which is highly resistant to weathering and may not have experienced major modifications. The bulk density is dependent on the particle sizes which are dominantly sandy and organic matter among others (Chaudhari et al., 2013). The cation exchange of the humid tropical regions are largely $\mathrm{pH}$ dependent and influenced more by soil texture than organic matter which has been reported to be very low.

Table 2: Statistical status and normality test of some soil properties in the study area

\begin{tabular}{|c|c|c|c|c|c|c|c|c|c|c|}
\hline \multicolumn{2}{|c|}{ 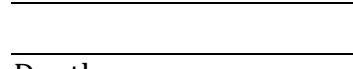 } & Range & Mean & Median & Mode & $\mathrm{CV}$ & Std. Dev. & Skewness & Kurtosis & $\operatorname{Pr}<W$ \\
\hline \multicolumn{2}{|c|}{ Depth } & 185.00 & 97.49 & 105.00 & 200.000 & 59.57 & 59.48 & 0.18 & -1.15 & 0.00 \\
\hline \multicolumn{2}{|c|}{ Horizon depth interval } & 80.00 & 35.73 & 32.00 & 40.00 & 44.52 & 15.91 & 1.88 & 3.99 & 0.00 \\
\hline \multirow{6}{*}{ 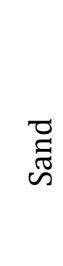 } & Very coarse & 100.00 & 59.93 & 58.8 & 40.00 & 36.90 & 22.13 & 0.29 & -0.67 & 0.00 \\
\hline & Coarse & 280.00 & 129.00 & 96.00 & 70.00 & 56.00 & 72.39 & 1.09 & -0.10 & 0.00 \\
\hline & Medium & 476.00 & 380.79 & 432.00 & 200.00 & 36.93 & 139.88 & -0.59 & -1.19 & 0.00 \\
\hline & Fine & 220.00 & 61.50 & 40.00 & 140.00 & 92.54 & 56.91 & 1.20 & 0.20 & 0.00 \\
\hline & Very fine & 360.00 & 259.68 & 252.00 & 200.00 & 24.13 & 62.67 & 1.07 & 2.06 & 0.00 \\
\hline & Total & 194.20 & 890.91 & 895.00 & 866.00 & 4.96 & 44.23 & -0.37 & -0.39 & $0.05^{*}$ \\
\hline \multicolumn{2}{|l|}{ Silt } & 65.80 & 22.94 & 22.2 & 14.00 & 61.43 & 14.11 & 0.64 & 0.26 & 0.00 \\
\hline \multicolumn{2}{|l|}{ Clay } & 183.80 & 85.19 & 77.4 & 22.20 & 45.59 & 38.84 & 0.74 & 0.38 & 0.00 \\
\hline \multicolumn{2}{|c|}{ Hydraulic conductivity } & 1.18 & 0.22 & 0.10 & 0.05 & 117.28 & 0.26 & 2.02 & 4.55 & 0.00 \\
\hline \multicolumn{2}{|c|}{ Bulk density } & 1.20 & 1.54 & 1.56 & 1.09 & 17.22 & 0.27 & -0.33 & -0.58 & $0.02^{* *}$ \\
\hline \multicolumn{2}{|c|}{ Organic carbon } & 3.11 & 1.37 & 1.4 & 0.28 & 57.29 & 0.78 & 0.07 & -1.04 & 0.00 \\
\hline \multicolumn{2}{|c|}{$\mathrm{pH}$} & 1.41 & 5.82 & 5.79 & 5.79 & 5.28 & 0.31 & 0.48 & -0.13 & 0.00 \\
\hline \multicolumn{2}{|c|}{ Electrical conductivity } & 0.63 & 0.07 & 0.02 & 0.01 & 154.00 & 0.11 & 2.86 & 8.99 & 0.00 \\
\hline \multicolumn{2}{|c|}{ Cation exc. capacity } & 5.50 & 4.68 & 4.70 & 3.50 & 24.28 & 1.14 & 0.28 & -0.57 & $0.06^{*}$ \\
\hline \multicolumn{2}{|c|}{ CECclay } & 0.82 & 0.20 & 0.09 & 0.05 & 104 & 0.21 & 1.38 & 0.95 & 0.00 \\
\hline
\end{tabular}

${ }^{*}$ and ${ }^{* *}$ Significant at $5 \%$ and $1 \%$ level of probability respectively

\section{Relationship between the terrain attributes and some profile soil characteristics}

The relationships between terrain attributes and soil profile characteristics within the coastal plain sands were as shown in Table 3. Terrain curvature comprising total, plan, profile and tangent is associated with the configuration of the landscape. Configuration and slope were major criteria for selection of the toposequences utilized in the study and their components have manifested their influence in the process of pedogenesis by dominating the significant correlation among the attributes used in the study.

Table 3. Correlation coefficients between the soil properties and terrain attributes of the study area

\begin{tabular}{|c|c|c|c|c|c|c|c|c|c|c|}
\hline \multirow{2}{*}{\multicolumn{2}{|c|}{ Soil properties }} & \multirow{2}{*}{ Aspect } & \multirow{2}{*}{ CTI } & \multirow{2}{*}{$\begin{array}{c}\text { Flow } \\
\text { Direction }\end{array}$} & \multicolumn{4}{|c|}{ Curvature } & \multirow{2}{*}{ Slope } & \multirow{2}{*}{ SPI } \\
\hline & & & & & Plan & Profile & Tangent & Total & & \\
\hline \multicolumn{2}{|c|}{ Profile depth } & 0.02 & -0.04 & -0.04 & 0.03 & -0.05 & 0.06 & 0.02 & 0.02 & -0.01 \\
\hline \multicolumn{2}{|c|}{ Horizon depth } & -0.07 & 0.03 & -0.12 & 0.03 & -0.04 & $0.21^{*}$ & 0.05 & 0.11 & 0.09 \\
\hline \multirow{6}{*}{ 苂 } & Very coarse & -0.14 & -0.01 & -0.03 & 0.10 & $0.30^{* *}$ & -0.03 & -0.14 & $-0.55^{* *}$ & $-0.56^{* *}$ \\
\hline & Coarse & -0.19 & 0.18 & -0.07 & $0.30^{* *}$ & $-0.26^{* *}$ & $-0.49 * *$ & $0.36^{* *}$ & -0.12 & -0.04 \\
\hline & Medium & 0.12 & -0.29 & 0.09 & 0.16 & 0.18 & $0.56^{* *}$ & $-0.25^{*}$ & 0.03 & 0.03 \\
\hline & Fine & 0.01 & 0.17 & $-0.22^{*}$ & $0.31^{* *}$ & $-0.33^{* *}$ & $-0.46^{* *}$ & $0.42^{* *}$ & $0.25^{*}$ & $0.25^{*}$ \\
\hline & Very fine & -0.03 & $0.22 *$ & -0.14 & $-0.30 * *$ & $0.29 * *$ & $-0.66^{* *}$ & $-0.35^{* *}$ & $0.66^{* *}$ & 0.12 \\
\hline & Total & -0.05 & 0.10 & $-0.28^{* *}$ & -0.01 & $0.29^{* *}$ & $0.28^{* *}$ & $-0.22 *$ & $0.20^{*}$ & $0.23^{*}$ \\
\hline \multicolumn{2}{|l|}{ Silt } & $0.38^{* *}$ & -0.17 & $0.33^{* *}$ & 0.03 & -0.11 & 0.15 & 0.13 & -0.17 & -0.16 \\
\hline \multicolumn{2}{|l|}{ Clay } & -0.08 & 0.19 & $0.22^{*}$ & 0.05 & $-0.32^{* *}$ & -0.20 & $0.25^{*}$ & $-0.21^{*}$ & $-0.24^{*}$ \\
\hline \multicolumn{2}{|c|}{ Hydraulic conductivity } & 0.07 & -0.14 & -0.14 & 0.06 & -0.06 & 0.07 & 0.07 & -0.03 & 0.01 \\
\hline \multicolumn{2}{|c|}{ Bulk density } & $0.25^{*}$ & -0.23 & 0.04 & 0.12 & 0.08 & 0.09 & 0.01 & -0.05 & -0.09 \\
\hline \multicolumn{2}{|c|}{ Organic carbon } & 0.17 & -0.16 & $0.38^{* *}$ & 0.02 & $-0.37 * *$ & $-0.33^{* *}$ & $0.24^{*}$ & 0.08 & 0.09 \\
\hline \multicolumn{2}{|c|}{$\mathrm{pH}$} & 0.22 & -0.17 & 0.01 & $-0.29 * *$ & $0.27^{* *}$ & $0.61^{* *}$ & $-0.34^{* *}$ & 0.12 & 0.14 \\
\hline \multicolumn{2}{|c|}{ Electrical conductivity } & -0.05 & 0.08 & -0.02 & $0.36^{* *}$ & 0.12 & $-0.56^{* *}$ & $0.23^{*}$ & -0.15 & -0.10 \\
\hline \multicolumn{2}{|c|}{ Cation exc. capacity } & $0.29 * *$ & 0.02 & $0.26^{* *}$ & -0.01 & -0.18 & -0.02 & 0.14 & 0.06 & 0.04 \\
\hline \multicolumn{2}{|c|}{ CECclay } & -0.03 & $0.21^{*}$ & $-0.22^{*}$ & $0.32^{* *}$ & -0.09 & $-0.62^{* *}$ & $0.28^{* *}$ & 0.14 & 0.16 \\
\hline
\end{tabular}


The results in Table 3 reveal that tangent curvature significantly correlated with horizon depth $(\mathrm{r}=0.21$, $\mathrm{p}<0.05$ ) and the entire particle size fraction except very coarse sand as with total curvature. Stream power index $(\mathrm{r}=-0.56)$, slope $(\mathrm{r}=-0.55)$ and profile curvature $(\mathrm{r}=0.30)$ are the terrain attributes that significantly correlated with very coarse sand. The stream power index is an estimate of effects of rainfall intensity and scouring inflow rate on runoff formation, soil erosion and solute transport on the surface runoff (Guo et al., 2010). This is an indication that these three terrain attributes play important role in the development of these profiles, thus supporting the view that pedogenesis of coastal plain sands is dependent on the particle size fraction which is dominated by coarse sand fractions (Obi, 2015b). The slope and aspect of a vegetated surface strongly affects the amount of solar radiation intercepted by that surface. Solar radiation is the dominant component of the surface energy balance and influences ecologically critical factors of microclimate, including near surface temperatures, evaporative demand and soil moisture content (Bennie et al., 2008). Aspect describes moisture and energy component of the landscape characteristics and was found to significantly correlate with silt content $(\mathrm{r}=0.38, \mathrm{p}<0.01)$, bulk density $(\mathrm{r}=0.25, \mathrm{p}<0.05)$ and cation exchange capacity $(r=0.29, p<0.01)$ of the soils. Bulk density and cation exchange capacity are influenced by moisture and temperature as a microclimatic phenomenon characteristically known as aspect and largely influence horizon morphology.

\section{Modelling of cation exchange capacity using terrain attributes}

The terrain attributes were modified by multiplying them with the bulk density and horizon depth which is a factor that could estimate the mass per unit depth of soil. The estimate of terrain attributes for a pedon is unity but the influence of terrain attribute within the profile will vary. This is because as different terrain attributes influences the landscape differently their effects are not the same with all horizons of the profile. This is simply because the different characteristics of the profile interact with each other. For instance moisture dynamics within the profile are influenced by the particle sizes that change both laterally and horizontally. In this case clay content with soils classified as ultisols will increase with depth and affect moisture dynamics. Therefore horizon characteristics modify the influence of the terrain attributes. The bulk density estimates the relationships between the components that made up soil and dependent on organic matter, texture, the density of soil mineral (sand, silt, and clay) and their packing arrangement. Bulk density typically increases with soil depth since subsurface layers are more compact and have lower organic matter, aggregation, and root penetration compared to surface layers, therefore they have lower pore spaces. Soil processes have been predicted with the aid of bulk density as horizon mass aggregation index (Bernoux et al., 1998; Calhoun et al., 2001).

It was possible to model the variability of the cation exchange capacity of the coastal plain sands using terrain attributes modified with bulk density and depth of each genetic horizon as shown in Table 4. The terrain attributes that were used in the modelling of cation exchange capacity were aspect and stream power index. The two terrain attributes influence moisture dynamics, energy distribution, physical movement of particles and solute transport. The coastal plain sands are dominated by kaolinitic clays and low organic carbon content that decrease with increase in depth within a profile, the consequence is the dependence of the cation exchange capacity solely on the clay content of the soils. Clay in soils classified as ultisol increases with increase in depth. The result revealed that clay is the only soil physical property considered in this study that influenced variability of cation exchange capacity (Table 4) and could be used in its prediction due to its role in the process of pedogenesis. Clay is intrinsically associated with stream power index as a major participant in the solute dynamics within soil profiles (Obi, et al., 2014; Obi, 2015a).

Table 4. Model of cation exchange capacity of coastal plain sands using terrain attributes and horizon interval

\begin{tabular}{|c|c|c|c|c|c|c|c|c|}
\hline Variable & Model & P-value & $\mathrm{R}^{2}$ & Observed & Predicted & $\operatorname{LSD}_{(0.05)}$ & RMSE & NRMSE \\
\hline CEC & $\begin{array}{l}3.62335+0.00005015 \\
\text { (aspect*bulk density*genetic } \\
\text { horizon depth) }-0.00119 \text { (stream } \\
\text { power index* bulk } \\
\text { density*genetic horizon depth) + } \\
\text { clay }\end{array}$ & 0.02 & 0.25 & 4.69 & 4.68 & 0.19 & 0.97 & 1.01 \\
\hline
\end{tabular}

The model accounted for approximately $25 \%$ of variability of cation exchange capacity of the profiles of coastal plain sand. The observed and predicted cation exchange capacity of the profiles were found not to be significantly $(\mathrm{p}<0.05)$ different from each other (Table 4). Root MSE and NRMSE for the model were 0.97 and 1.01 respectively indicating the superiority of the model and its capacity to predict especially for use in soil classification and management. The prediction model revealed the effectiveness of modification of the 
terrain characteristics with the bulk density and genetic horizon depth. The dimension of the factors of bulk density and horizon depth results to mass per unit area of soil as shown below:

$$
\begin{gathered}
\text { Bulk density }=\frac{\text { mass }}{\text { volume }}=\frac{g}{\mathrm{~cm}^{3}} \\
\text { Horizon depth }=\mathrm{cm} \\
\text { Bulk density x horizon depth }=\frac{\mathrm{g}}{\mathrm{cm}^{3}} \times \mathrm{cm}=\frac{\mathrm{g}}{\mathrm{cm}^{2}}=\text { mass per unit area }
\end{gathered}
$$

The above formula is an indication that the aspect, stream power index and mass per unit area of soil and clay content could effectively provide appropriate information on the cation exchange capacity of profiles formed on the gently undulating profiles of coastal plain sands.

\section{Conclusion}

The soil profile characteristics considered for the prediction of cation exchange capacity of coastal plain sands were easily determinable, inexpensive and associated with other soil properties. These include particle size fractions, hydraulic conductivity, bulk density, organic carbon, $\mathrm{pH}$ and electrical conductivity. Most of the soil properties were not normally distributed except sand, bulk density and cation exchange capacity which possess characteristics that are more associated with their geogenic than pedogenic origin. The profile characteristics that were non-normally distributed were those that are usually influenced by pedogenesis and since the landscape characteristics and genesis are different, then they are from different populations and their characteristics should not be normally distributed. The terrain attributes that could be used to predict cation exchange capacity of the coastal plain sands were aspect and stream power index modified by genetic horizon depth, bulk density and clay content.

\section{References}

Behrens, T., Zhu, A.X., Schmidt, K., Scholten, T., 2010. Multi-scale digital terrain analysis and feature selection for digital soil mapping. Geoderma 155(3-4): 175-185.

Bennie, J., Huntley, B., Wiltshire, A., Hill, M.O., Baxter, R., 2008. Slope, Aspect and climate: Spatially explicit and implicit models of topographic microclimate in chalk grassland. Ecological Modelling 216(1): 47-59.

Bernoux, M., Cerri, C., Arrouays, D., Jolivet, C., Volkoff, B., 1998. Bulk densities of Brazilian Amazon soils related to other soil properties. Soil Science Society of America Journal 62(3): 743-749.

Calhoun, F. G., Smeck, N. E., Slater, B. L., Bigham, J. M., Hall, G. F. 2001. Predicting bulk density of Ohio soils from morphology, genetic principles, and laboratory characterization data. Soil Science Society of America Journal 65(3): 811-819.

Carson, M.A., Kirkby, M.J., 1972. Hillslope form and process, Cambridge University Press, New York, USA. 484p.

Chaudhari, P.R., Ahire, D.V., Ahire, V.D., Chkravarty, M., Maity, S. 2013. Soil bulk density as related to soil texture, organic matter content and available total nutrients of Coimbatore soil. International Journal of Scientific and Research Publications 3(2):1-8.

Dane, J.H., Topp, G.C., 2002. Methods of soil analysis Part 4: physical methods. Soil Science Society of America Book Series, Vol. 5, Madison, WI, USA. 1692p.

Debella-Gilo, M., Etzelmuller, B., Klakegg, O., 2007. Digital soil mapping using digital terrain analysis and statistical modelling integrated into GIS: examples from Vestfold county of Norway. ScanGIS 2007 - Proceedings of the $11^{\text {th }}$ Scandinavian Research Conference on Geographical Information Sciences. $5^{\text {th }} 7^{\text {th }}$ September 2007, Ås, Norway. pp. 237-253.

Gou, T., Wang, Q., Li, D., Wu, L. 2010. Sediment and solute transport on soil slope under simultaneous influence of rainfall impact and scouring flow. Hydrological Processes 24(11): 1446-1454.

Lekwa, A.G., Whiteside, E.P., 1986. Coastal plain soils of Southeastern Nigeria: I. Morphology, classification, and genetic relationships. Soil Science Society of America Journal 50(1): 154-160.

Ma, C., Eggleton, R.A. 1999. Cation exchange capacity of kaolinite. Clays and Clay Minerals 47(2): 174-180.

McLean, E.O., 1982. Soil pH and lime requirement. In: Methods of Soil Analysis Part 2. Chemical and Microbiological Properties. Page, A.L., Miller, R.H., Keen, D.R. (Eds.). ASA-SSSA, Agronomy Monograph 9.2, Madison, WI, USA. pp. 199-223.

Moore, I.D., Gessler, P.E., Nielsen, G.A, Petersen, G.A., 1993, Soil attribute prediction using terrain analysis. Soil Science Society America Journal 57(2): 443-452.

Moss R.P., 1957, Report on the Classification of soils found over sedimentary rocks in Western Nigeria. Soil Survey Report No. 67. IAR and The University of Ife, Nigeria.

Obi, J.C., Udoh, B.T., 2011. Identification of soil management factors from spatially variable soil properties of coastal plain sands in Southeastern Nigeria. Open Journal of Soil Science 1(2): 25-40.

Obi, J.C., Ogban, P.I., Ituen, U.J., Udoh, B.T., 2014. Development of pedotransfer functions for coastal plain soils using terrain attributes. Catena 123: 252-262.

Obi, J.C., 2015a. Prediction of characteristics of coastal plain soils using terrain attributes. Agro-Science 14(3): 22-26. 
Obi, J.C., 2015b. Particle size fractions and pedogenesis of coastal plain sands. Archives of Agronomy and Soil Science 61(10): 1-18.

Obi, J.C., Ibia, T.O., Eshiet, P.B., 2016. Effect of land use on potassium form of coastal plain sands of Nigeria, Chemistry and Ecology 32(3): 238-258.

Odu, C.T.I., Babalola, O., Udo E.J., Ogunkunle, A.O., Bakare, T.A., Adeoye, G.O., 1986. Laboratory Manual for Agronomic Studies in Soil, Plant and Microbiology, University of Ibadan. Nigeria. Pp. 50-54.

Ofomata, G.E.K., 1981. Actual and potential erosion in Nigeria and measures for control. In: Acid sands of southeastern Nigeria. Udo, E.J., Sobulo, R.A. (Eds.). Special Publication Monograph No. 1. Ibadan, Nigeria. Soil Science Society of Nigeria. pp. 151-165.

Ojanuga, A.G., Lekwa, G., Akamigbo, F.O.R., 1981. Survey classification and genesis of acid soils. In: Acid sands of southern Nigeria. Udo, E.J., Sobulo, R.A. (Eds.). Special Publication Monograph No. 1. Ibadan, Nigeria. Soil Science Society of Nigeria; pp. 1-20.

Rhoades, J. D. 1996. Salinity: electrical conductivity and total dissolved solids. In: Methods of soil analysis: Part 3. chemical methods, Sparks, D.L. (Ed.). ASA-SSSA, Madison, WI, USA, pp. 417-435.

SAS Institute, 2011. SAS Systems for Information Delivery for Windows. Version 9.2. SASß. Institute Inc., Cary, NC, USA.

Seibert, J., Stendahl, J., Sørensen, R., 2007. Topographical influences on soil properties in boreal forests. Geoderma 141(1-2): 139-148.

Shapiro, S.S., Wilk, M.B., 1965. An analysis of variance test for normality. Biometrika 52(3-4): 591-611.

Smyth, A.J., Montgomery, R.F., 1962. Soils and Land use in Central Western Nigeria, Government Printers, Ibadan.

Sparks, D.L., 1996. Methods of soil analysis Part 3 Chemical methods. Soil Science Society of America. Book Series No. 5. ASA, SSSA, Madison, WI, USA.

Swarowsky, A., Dahlgren, R.A., Tate, K.W., Hopmans, J.W., O'Geen, A.T., 2011. Catchment scale soil water dynamics in a Mediterranean-type oak woodland. Vadose Zone Journal 10(3): 800-815.

Udosen, C., 2014. Gully Erosion and cities: an unwanted partnership. Being the first in the series of Faculty of Social Science Lectures, University of Uyo, Uyo. Pampas Digital Publications, Uyo. 67p. 